\title{
RXRa ligand Z-10 induces PML-RARa cleavage and APL cell apoptosis through disrupting PML-RARa/RXRa complex in a cAMP-independent manner
}

\author{
Lin $X \mathbf{u}^{1, *}$, Zhiping Zeng ${ }^{1, *}$, Weidong Zhang ${ }^{1}$, Gaoang Ren ${ }^{1}$, Xiaobin Ling ${ }^{1}$, Fengyu \\ Huang $^{1}$, Peizhen Xie ${ }^{1}$, Ying Su ${ }^{1,2}$, Xiao-kun Zhang ${ }^{1,2}$, Hu Zhou ${ }^{1}$ \\ ${ }^{1}$ School of Pharmaceutical Sciences, Fujian Provincial Key Laboratory of Innovative Drug Target Research, Xiamen \\ University, Xiamen, Fujian, China \\ ${ }^{2}$ Cancer Center, Sanford Burnham Prebys Medical Discovery Institute, La Jolla, California, USA \\ *These authors have contributed equally to this work \\ Correspondence to: Hu Zhou, email: huzhou@xmu.edu.cn \\ Xiao-kun Zhang, email: xkzhang@xmu.edu.cn
}

Keywords: Z-10, RXRa, PML-RARa, interaction, cleavage

Received: June 29, $2016 \quad$ Accepted: December 27, $2016 \quad$ Published: January 25, 2017

\section{ABSTRACT}

The major oncogenic driver of acute promyelocytic leukemia (APL) is the fusion protein PML-RARa originated from the chromosomal translocation $t(15 ; 17)$. All-trans retinoic acid (ATRA) and arsenic trioxide cure most patients by directly targeting PMLRARa. However, major issues including the resistance of ATRA and arsenic therapy still remain in APL clinical management. Here we showed that compound Z-10, a nitro-ligand of retinoid $X$ receptor a ( $R X R a)$, strongly promoted the cAMP-independent apoptosis of both ATRA- sensitive and resistant NB4 cells via the induction of caspasemediated PML-RARa degradation. RXRa was vital for the stability of both PML-RARa and RARa likely through the interactions. The binding of Z-10 to RXRa dramatically inhibited the interaction of RXRa with PML-RARa but not with RARa, leading to Z-10's selective induction of PML-RARa but not RARa degradation. Z-36 and Z-38, two derivatives of Z-10, had improved potency of inducing PML-RARa reduction and NB4 cell apoptosis. Hence, RXRa ligand Z-10 and its derivatives could target both ATRA- sensitive and resistant APL cells through their distinct acting mechanism, and are potential drug leads for APL treatment.

\section{INTRODUCTION}

Acute promyelocytic leukemia (APL) originates from the specific chromosomal translocations mostly between chromosomes 15 and 17, leading to the occurrence of the fused oncogene promyelocytic leukemia - retinoic acid receptor- $\alpha$ (PML-RAR $\alpha$ ) [1]. The corresponding chimeric protein PML-RAR $\alpha$ is most often the only driving factor of APL initiation $[2,3]$. PMLRAR $\alpha$ binds to RAR $\alpha$ cognate DNA elements and inhibits RAR $\alpha$-mediated transcription of differentiation genes, leading to the differentiation block of promyelocytes [2, 4]. PML is the organizer of a nuclear structure known as the PML nuclear bodies (NBs), which is important for maintaining cellular homeostasis $[5,6]$. Another pathogenic activity of PML-RAR $\alpha$ is to disrupt the PML nuclear bodies through its interaction with PML [7].
All-trans-retinoic acid (ATRA) induces the transcriptional activity of PML-RAR $\alpha$, leading to the induction of RAR $\alpha$-targeted genes and the differentiation of promyelocyte [2]. ATRA also triggers proteasomeand caspase-mediated degradation of PML-RAR $\alpha$ to contribute its efficacy [8-10]. However, ATRA at pharmacological concentration strongly stimulates the transactivation and degradation of RAR, resulting in some RAR-related adverse effects [11, 12]. Also, long term exposure of ATRA often results in the relapse likely due to the mutated RAR $\alpha$ moiety in PML-RAR $\alpha$ [13, 14]. Arsenic trioxide binds to the PML moiety, leading to SUMO-dependent and ubiquitin-mediated degradation of PML-RAR $\alpha[15,16]$. The reduction of PML-RAR $\alpha$ sensitizes APL cells to the apoptotic signals triggered by arsenic [17]. Because arsenic targets to the PML moiety, it can overcome ATRA-resistance in some cases [13]. 
However, APL driven by the PLZF-RAR $\alpha$ and PMLRAR $\alpha$ with point mutations in the PML moiety such as A216V are resistant to arsenic $[18,19]$. Thus, novel drugs with different therapeutic mechanisms are desperately needed to overcome the resistance and adverse effects of ATRA and/or arsenic.

Retinoid X receptor- $\alpha(\operatorname{RXR} \alpha)$ is a unique nuclear receptor due to its ability to form heterodimers with many other nuclear receptors [20]. It has been elucidated that PML-RAR $\alpha$ forms homodimer mediated by the PML moiety, and RXR $\alpha$ binds to PML-RAR $\alpha$ through the $\mathrm{RAR} \alpha$ moiety to form heterotetramer [21]. $\mathrm{RXR} \alpha$ is required for the sumoylation of PML-RAR $\alpha$ and PML RAR $\alpha$ efficient binding to DNA, both of which are necessary for PML-RAR $\alpha$-mediated transformation [2225]. Several RXR $\alpha$ ligands such as SR11237 and BMS749 trigger the differentiation and apoptosis of APL cells, but they have to work together with cAMP for efficient action $[26,27]$, leading to the additional side effects from cAMP. Thus, whether some RXR $\alpha$ ligands alone could show striking anti-APL effect is worthy of investigation.

We recently reported that Z-10, a nitro-ligand of $\operatorname{RXR} \alpha$, binds to $\mathrm{RXR} \alpha$ with a distinct binding mode and induces a unique conformational change of $\operatorname{RXR} \alpha$ [28]. In the current study, we report that Z-10 induced PMLRAR $\alpha$ degradation and the apoptosis of both ATRAsensitive and resistant APL cells in a cAMP-independent manner.

\section{RESULTS}

\section{Z-10 induces NB4 cell apoptosis}

RXR $\alpha$ ligands together with cAMP have shown striking anti-APL activities [26, 27]. Recently, we unraveled that $\mathrm{Z}-10$ is a $\mathrm{RXR} \alpha$ nitro-ligand with strong growth inhibition and apoptotic induction of MCF-7 breast cancer cells [28]. We therefore explored the activities of Z-10 on the differentiation and apoptosis induction of NB4 cells, a human APL cell line with PML-RAR $\alpha$ oncogene [29] (Figure 1). Differentiation induction of Z-10 on NB4 cells was examined by flow cytometry following CD11b the surface differentiation marker staining. As previously reported, ATRA at $1 \mu \mathrm{M}$ concentration significantly triggered NB4 cell differentiation, as shown by the increased CD11b staining $(0.65 \%$ CD $11 \mathrm{~b}$ positive cells at DMSO treatment to $30.35 \%$ at ATRA treatment) (Figure $1 \mathrm{~B}$ and Supplementary Figure 1). In comparison, Z-10 at 1 and $2 \mu \mathrm{M}$ concentrations only had, if there was, minor effect (Figure 5A and Supplementary Figure 3). Z-10 at $3 \mu \mathrm{M}$ and arsenic at $1 \mu \mathrm{M}$ had much weaker effect than ATRA at $1 \mu \mathrm{M}$ on differentiation induction of NB4 cells (Figure 1B and 5A and Supplementary Figure 1 and 3). The apoptotic effect of Z-10 on NB4 cells was examined through Annexin V-FITC/PI double staining assay. Both Z-10 and arsenic at $1 \mu \mathrm{M}$ significantly promoted NB4 cell apoptosis comparing with ATRA (8.07\%, 7.38\% and $4.76 \%$ NB4 cells underwent apoptosis in the presence of Z-10, arsenic, and ATRA, respectively) (Figure 1C). In addition, the apoptotic induction of Z-10 was in a dosedependent manner (Figure 1C). These results suggested that Z-10 was of potent capability on inducing NB4 cell apoptosis.

\section{Z-10 destabilizes PML-RARa}

Through the induction of PML-RAR $\alpha$ degradation, arsenic promotes the apoptosis of APL cells [17]. Thus, we explored whether Z-10 affected the stability of PMLRAR $\alpha$. Figure $2 \mathrm{~A}$ and $2 \mathrm{~B}$ showed that Z-10 time- and dose- dependently induced PML-RAR $\alpha$ reduction in the absence of cAMP. In the presence of cycloheximide (CHX), Z-10 still induced PML-RAR $\alpha$ reduction in a timedependent manner, indicating that Z-10 destabilized PMLRAR $\alpha$ protein (Figure $2 \mathrm{C}$ ). The small fragments of PMLRAR $\alpha$ induced by Z-10 suggested that Z-10 destabilized PML-RAR $\alpha$ through cleavage (Figure 2A-2C). Z-10induced PML-RAR $\alpha$ reduction and cleavage were strongly inhibited by z-VAD-FMK but only slightly prevented by MG132, implying that caspases but not proteasome was mainly responsible for the degradation and cleavage of PML-RAR $\alpha$ (Figure 2D). Z-11 (Figure 1A), an isomer of $\mathrm{Z}-10$, also binds to $\mathrm{RXR} \alpha$ but induces a distinct $\mathrm{RXR} \alpha$ conformation [28]. Different from Z-10, Z-11 failed to trigger PML-RAR $\alpha$ reduction (Figure 2E), indicating the selectivity of $\mathrm{RXR} \alpha$ nitro-ligands. Additionally, the strong ability of Z-10 on inducing PML-RAR $\alpha$ reduction was unique among RXR $\alpha$ ligands examined (Figure $2 \mathrm{~F}$ ). Therefore, results from above study showed that Z-10 down-regulated PML-RAR $\alpha$ mainly through caspasemediated cleavage in a cAMP independent manner, which might trigger the apoptosis of NB4 cells. This may also explain why Z-10 induced dramatic apoptosis in NB4 cells but not in THP1 cells that do not possess PML-RAR $\alpha$ oncoprotein (Supplementary Figure 2).

\section{Z-10 inhibits the interaction of PML-RAR $\alpha$ and RXRa}

We evaluated whether Z-10 activated caspases to cleave PML-RAR $\alpha$. Caspase activator PAC-1 could induce PML-RAR $\alpha$ degradation only when caspase 3 was highly activated, showing from the simultaneous events of PML-RAR $\alpha$ decreased and cleaved caspase 3 increased expressions. However, PML-RAR $\alpha$ degradation induced by Z-10 was an earlier event before the weak activation of caspase 3 (Figure 3A). This suggested that Z-10-induced PML-RAR $\alpha$ degradation may not, at least not completely, depend on caspase activation. The binding of RXR $\alpha$ to PML-RAR $\alpha$ has been implicated in the development of APL [2]. We then examined the possibility of RXR $\alpha$ regulating PML-RAR $\alpha$ stability. 
When NB4 cells were transfected with siRNA to reduce RXR $\alpha$ expression, the expression levels of both PMLRAR $\alpha$ and RAR $\alpha$ were accordingly reduced (Figure 3B), suggesting that RXR $\alpha$ binding stabilizes PML-RAR $\alpha$ and RAR $\alpha$. We hypothesized that Z-10 could bind to RXR $\alpha$ and inhibit the interaction of RXR $\alpha$ and PML-RAR $\alpha$, thereby leading to the instability of PML-RAR $\alpha$. Our co immunoprecipitation assay showed that PML-RAR $\alpha$ and $\mathrm{RXR} \alpha$ overexpressed in Cos-7 cells formed strong complex, which was largely disrupted by Z-10 (Figure 3C$3 \mathrm{D}$ and $4 \mathrm{C}$ ). It has been reported that $\mathrm{Z}-10$ fails to bind to RXR $\alpha / \mathrm{C} 432 \mathrm{~S}$ mutant with cysteine 432 substituted<smiles>O=[N+]([O-])C=Cc1cccc2ccccc12</smiles>
Z-10<smiles>O=[N+]([O-])/C=C/c1ccc2ccccc2c1</smiles>

Z-11<smiles>[Z5][R5]c1ccc(C)c(/C=C/[N+](=O)[O-])c1/C=C\[N+](=O)[O-]</smiles><smiles></smiles>
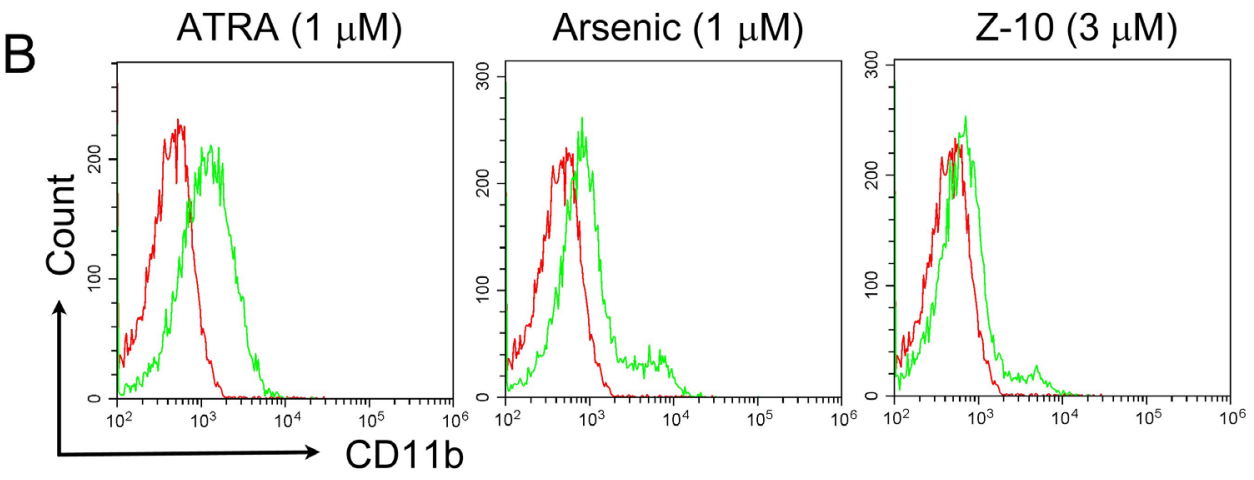

C

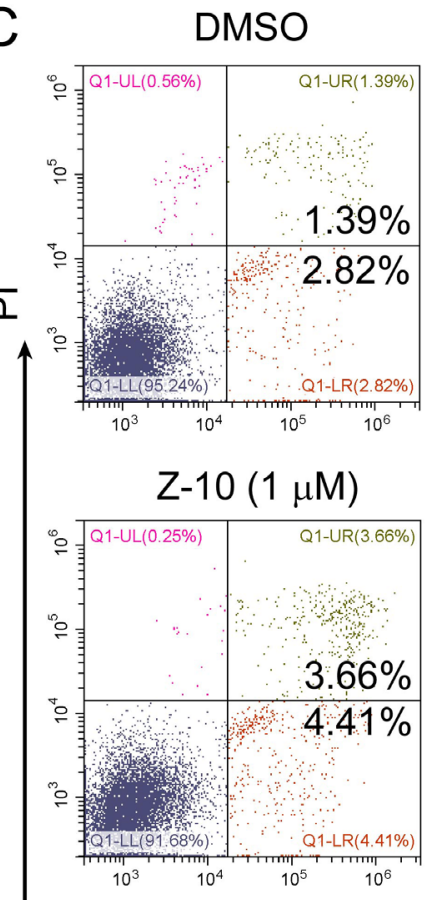

ATRA $(1 \mu \mathrm{M})$
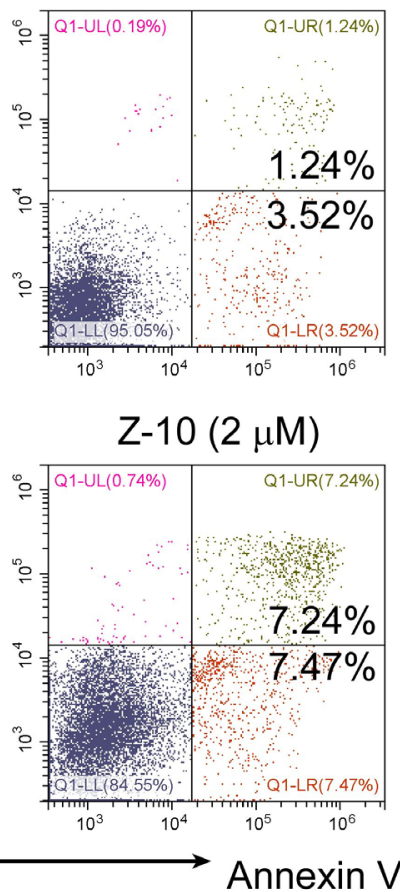

Arsenic $(1 \mu \mathrm{M})$
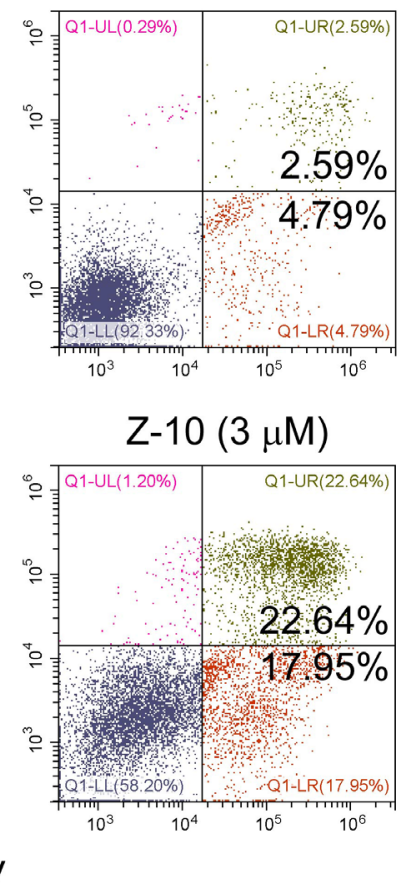

Figure 1: NB4 cell apoptosis induction by Z-10. A. The structures of Z serial compounds. B. NB4 cells were incubated with ATRA $(1 \mu \mathrm{M})$, arsenic $(1 \mu \mathrm{M})$ or Z-10 $(3 \mu \mathrm{M})$ for two days, and CD11b-positive cells were counted by flow cytometry. Cells treated with DMSO were plotted in red, and cells treated with compounds were plotted in green. C. Detection of apoptotic cells by Annexin V-FITC and Propidium iodide (PI) double staining in NB4 cells after incubated with ATRA, arsenic or Z-10 at the indicated concentrations for 36 hours. 
with serine [28]. We found that Z-10 also failed to inhibit the interaction of PML-RAR $\alpha$ and RXR $\alpha / C 432 \mathrm{~S}$ (Figure 3D), which indicated that Z-10 inhibiting RXR $\alpha$ and PML/ $\mathrm{RAR} \alpha$ interaction relied on its binding to $\mathrm{RXR} \alpha$. In Cos7 cells, overexpressed $\mathrm{RXR} \alpha$ prevented $\mathrm{Z}-10$ induced PML-RAR $\alpha$ degradation to a certain extent (Figure 3E). Therefore, RXR $\alpha$ binding could stabilize PML-RAR $\alpha$, and the disruption of the RXR $\alpha / P M L R A R ~ \alpha$ complex by Z-10 resulted in the instability of PML-RAR $\alpha$. Our data also suggested that the basal activity of caspases was able to induce PML-RAR $\alpha$ cleavage once the PML-RAR $\alpha / R X R \alpha$ complex was disrupted by Z-10.

\section{Z-10 has no effect on RAR $\alpha$ stability}

Because ATRA could bind to both PML-RAR $\alpha$ and $\operatorname{RAR} \alpha$, one unavoidable side effect of ATRA originates from its strong induction of RAR $\alpha$ activation and degradation when patients are treated with ATRA at pharmacologic concentrations $[30,31]$. Consistently, we found that ATRA at $1 \mu \mathrm{M}$ potently induced RAR $\alpha$ degradation in NB4 cells (Figure 4A). However, Z-10 only induced PML-RAR $\alpha$ degradation and had no apparent effect on the expression level of RAR $\alpha$ in NB4 cells (Figure 4A). Similarly, Z-10 dramatically promoted the degradation of overexpressed PML-RAR $\alpha$ but not RAR $\alpha$ in Cos-7 cells (Figure 4B). As expected, Z-10 failed to inhibit the interaction of $\operatorname{RAR} \alpha$ and $\operatorname{RXR} \alpha$ as did to the interaction of PML RAR $\alpha$ and $\mathrm{RXR} \alpha$ (Figure 4C). Thus, Z-10 induction of PML-RAR $\alpha$ but not RAR $\alpha$ degradation was due to its selective inhibition of $\mathrm{RXR} \alpha$ interaction with PML-RAR $\alpha$ but not with RAR $\alpha$.

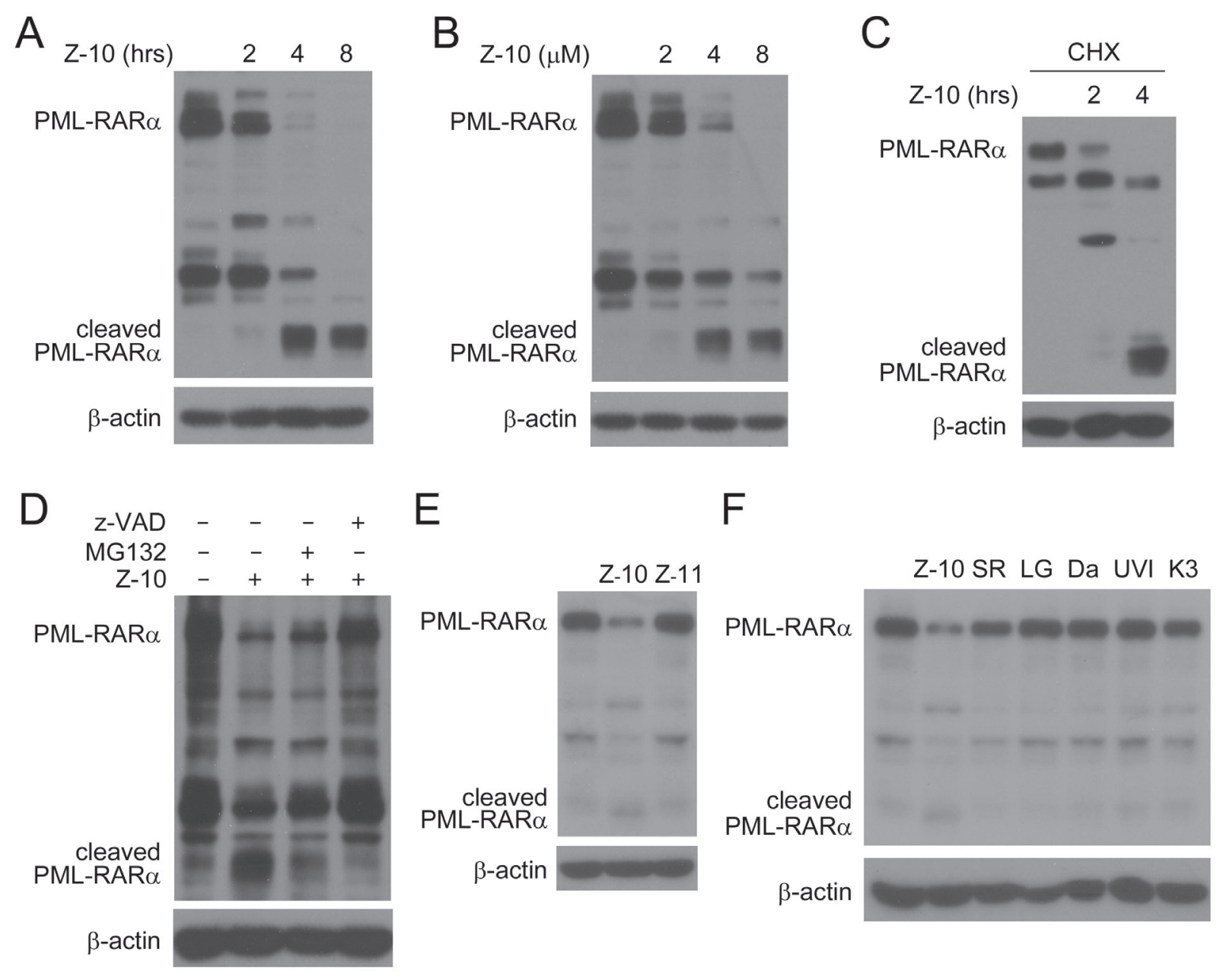

Figure 2: PML-RARa reduction induced by Z-10 through cleavage. A-B. NB4 cells were treated with $5 \mu \mathrm{M}$ of Z-10 for the indicated time (A) or treated for 4 hours with the indicated concentrations (B), and PML-RAR $\alpha$ expression was analyzed by western blot using anti-RAR $\alpha$ antibody. The expression of $\beta$-actin was used as a loading control. C. NB4 cells were treated with $50 \mu \mathrm{g} / \mathrm{mL}$ cycloheximide $(\mathrm{CHX})$ for 4 hours and $5 \mu \mathrm{M} \mathrm{Z}-10$ for 2 or 4 hours. Protein expression was analyzed by western blot. D. NB4 cells were treated with $5 \mu \mathrm{M}$ Z-10 together with $20 \mu \mathrm{M}$ MG132 or $20 \mu \mathrm{M}$ z-VAD-FMK (z-VAD) for 4 hours, and protein expression was examined by western blot. E-F. NB4 cells were treated with $5 \mu \mathrm{M}$ compounds as indicated for 4 hours, and PML-RAR $\alpha$ protein was detected by western blot. SR, LG, Da, UVI and K3 represent SR11237, LG100745, Danthron, UVI3003 and K-8003, respectively. 


\section{Z-10 induces PML-RAR $\alpha$ degradation and apoptosis in ATRA-resistant NB4 cells}

ATRA is a widely used and effective clinical drug for APL $[32,33]$. However, a fraction of APL is refractory to ATRA due to long-term ATRA treatment and PMLRAR $\alpha$ mutations $[13,14]$. As previously reported, ATRA could strongly induce the differentiation of NB4 cells but not NB4-LR1 and NB4-LR2 cells, two ATRA-resistant cell lines [14, 34] (Figure 5A and Supplementary Figure 3). Consistently, ATRA promoted PML-RAR $\alpha$ degradation only in NB4 cells but not in NB4-LR1 or NB4-LR2 cells (Figure 5B and 5D). However, Z-10 was able to induce PML-RAR $\alpha$ degradation in all the three cell lines (Figure 5B-5E). Also, Z-10 dose- and time-dependently induced PML-RAR $\alpha$ reduction and cleavage in both NB4-LR1 and NB4-LR2 cell lines mainly through caspase-mediated pathway (Figure 5C-5F). Similarly, Z-10 did not affect the expression of RAR $\alpha$ in NB4-LR1 cells (Figure 5D). Although Z-10 did not show apparent differentiation induction of NB4-LR1 and NB4-LR2 cells (Figure 5A and Supplementary Figure 3), it significantly promoted
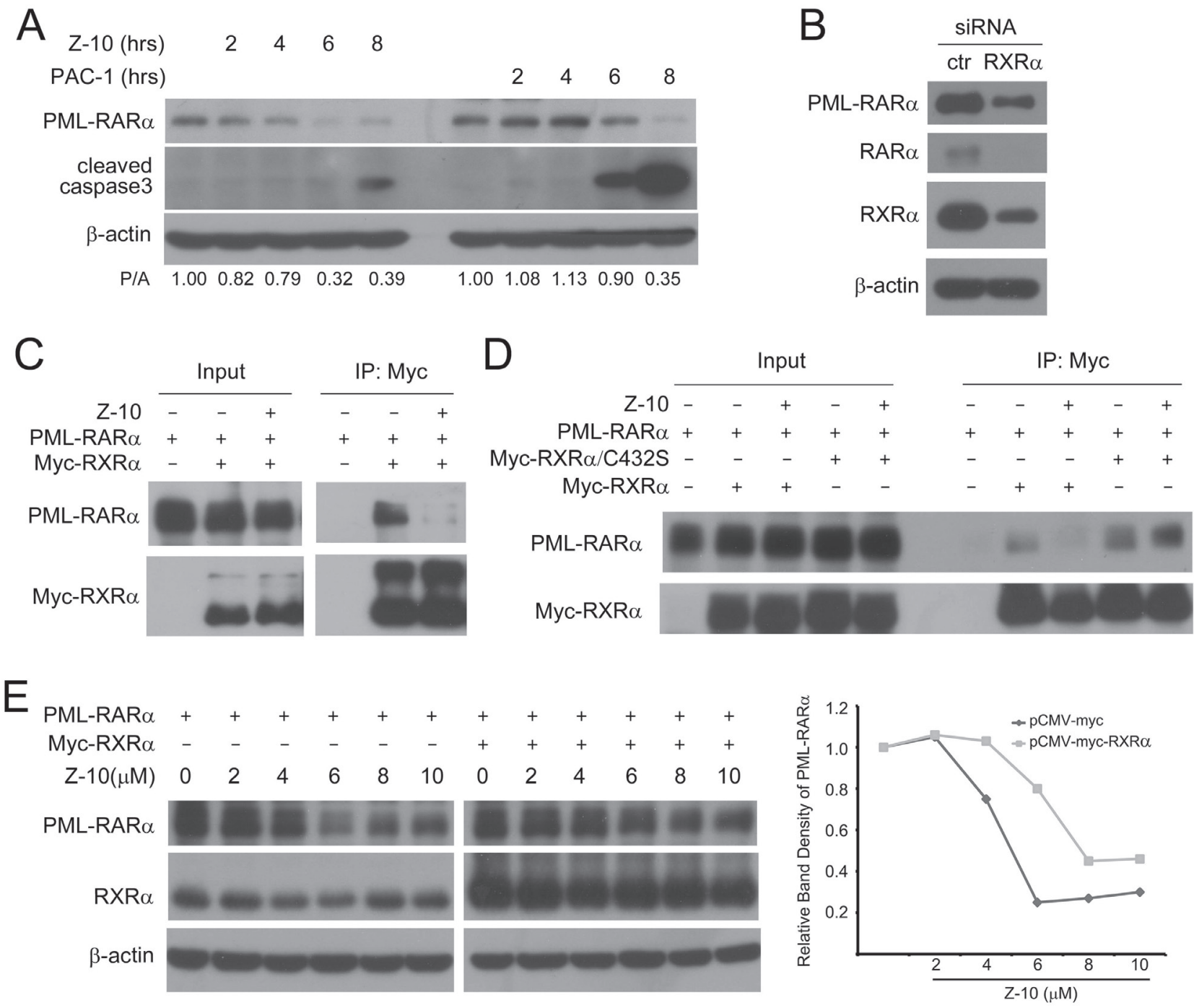

Figure 3: The inhibition of PML-RAR $\alpha / \mathbf{R X R} \boldsymbol{\alpha}$ complex formation by Z-10. A. NB4 cells were treated with $5 \mu \mathrm{M} Z-10$ or 50 $\mu \mathrm{M}$ PAC-1 for the indicated time, and the expression of PML-RAR $\alpha$ and cleaved caspase 3 was analyzed by western blot. Relative protein band densities after normalization to $\beta$-actin signal were shown at the bottom of the figure (P/A represents PML-RAR $\alpha / \beta$-actin). B. NB4 cells were infected with sh RXR $\alpha$ or sh control retrovirus for three days. Protein expression levels were analyzed by western blot. C-D. Cos7 cells were transfected with the indicated plasmids for 24 hours and then treated with $5 \mu \mathrm{M}$ of Z-10 for 4 hours. The complex formations were examined by co-immunoprecipitation and western blot using the indicated antibodies. E. Cos-7 cells were transfected with PMLRAR $\alpha$ expression plasmid alone or together with Myc-RXR $\alpha$ plasmid for 24 hours, and treated with Z-10 at the indicated concentrations for 4 hours. Protein expression levels were analyzed by western blot. Relative PML-RAR $\alpha$ band densities after normalization to $\beta$-actin were plotted. 
the apoptosis of these two cell lines in a dose-dependent manner (Figure 5G). Thus, Z-10 could induce PML-RAR $\alpha$ degradation and apoptosis in ATRA-resistant NB4 cells.

\section{Z-36 and Z-38 are optimized Z-10 derivatives}

To improve the potency of Z-10, we synthesized a series of Z-10 derivatives and examined their effects in NB4 cells. Among the synthesized Z-10 derivatives examined, we found that Z-37 had similar ability as Z-10 while Z-36 and Z-38 possessed stronger ability than Z-10 on inducing PML-RAR $\alpha$ degradation (Figure $1 \mathrm{~A}$ and Figure $6 \mathrm{~B})$. In consistent with their ability on degrading PML-RAR $\alpha$, Z-36 and Z-38 showed stronger potency on inhibiting NB4 cell viability (The $\mathrm{IC}_{50}$ of Z-10, Z-36 and Z-38 were 4.284, 0.7476 and $0.713 \mu \mathrm{M}$, respectively). Z-36 and Z-38 also displayed stronger apoptosis induction of NB4 and NB4-LR1 cells than Z-10 (Figure 6D). Z-10 and its derivatives exhibited similar stimulating effect of $\mathrm{RXR} \alpha$ transactivation (Figure 6A), suggesting that their anti-APL ability was not directly correlated to their activation of $\mathrm{RXR} \alpha$ transactivation.

\section{DISCUSSION}

Although ATRA and arsenic have improved the overall survival rate of APL patients [35, 36], there exist major issues in the APL treatment such as ATRA and arsenic resistance as well as their off target side effects [18, 19, 37]. In our current study, we provided a potential drug lead that may overcome ATRA-resistance and ATRA-related side effects through its distinct acting mode.

Z-10, as the first identified nitro-ligand of $\operatorname{RXR} \alpha$, has distinct properties from classic RXR $\alpha$ ligands in both molecular structures and RXR $\alpha$-dependent activities [28]. cAMP-dependent and PKA-catalyzed phosphorylation of PML-RAR $\alpha$ is crucial for some RXR $\alpha$ ligands to efficiently induce PML-RAR $\alpha$ degradation and APL cell apoptosis $[38,39]$. Here, we showed that Z-10 is unique among RXR $\alpha$ ligands in that it has strong anti-APL

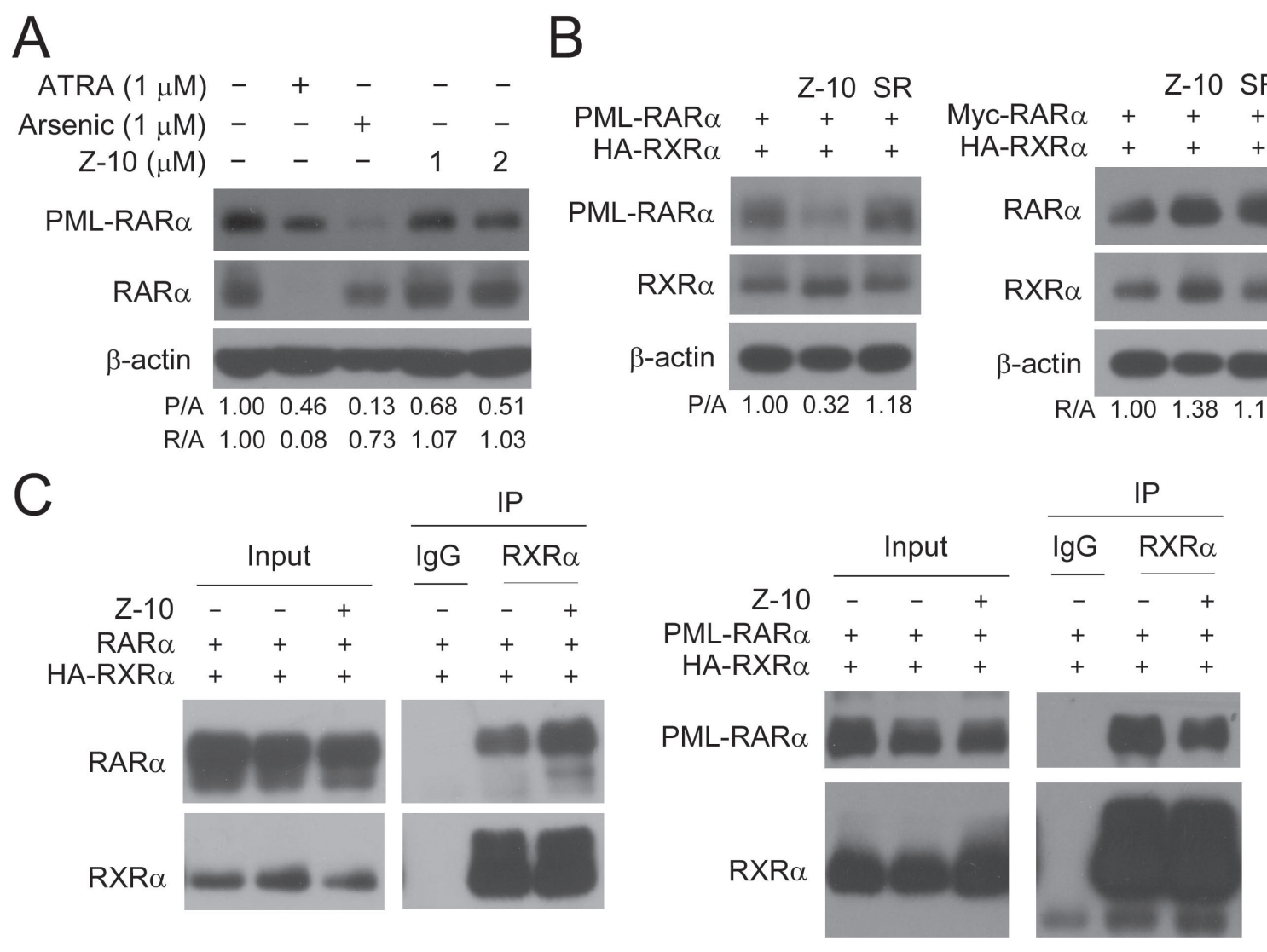

Figure 4: Z-10 had no effect on the stability of RAR $\alpha$. A. NB4 cells were incubated with Z-10, arsenic or ATRA for 48 hours. The PML-RAR $\alpha$ and RAR $\alpha$ protein was detected by anti-RAR $\alpha$ antibody with $\beta$-actin as a loading control. Relative protein band densities after normalization to $\beta$-actin signal were shown at the bottom of the figure (P/A represents PML-RAR $\alpha / \beta$-actin, and R/A represents RAR $\alpha / \beta$ actin). B. Cos-7 cells were transfected with the indicated plasmids for 24 hours, and then treated with $5 \mu$ M of Z-10 or SR11237 (SR) for 6 hours. Protein expression levels were analyzed by western blot. C. Cos-7 cells were transfected with the indicated plasmids for 24 hours and then treated with $5 \mu \mathrm{M}$ of Z-10 for 4 hours. The complex formations were examined by co-immunoprecipitation using the indicated antibodies. 
activity in the absence of cAMP (Figure 1 and Figure 2). This should, at least in part, be attributed to its induction of a distinct $\mathrm{RXR} \alpha$ conformation, resulting in the dissociation of PML-RAR $\alpha$ from RXR $\alpha$ (Figure 3C-3D and Figure 4C). The cAMP-independent PML-RAR $\alpha$ degradation by Z-10 also suggested that Z-10 may represent a promising

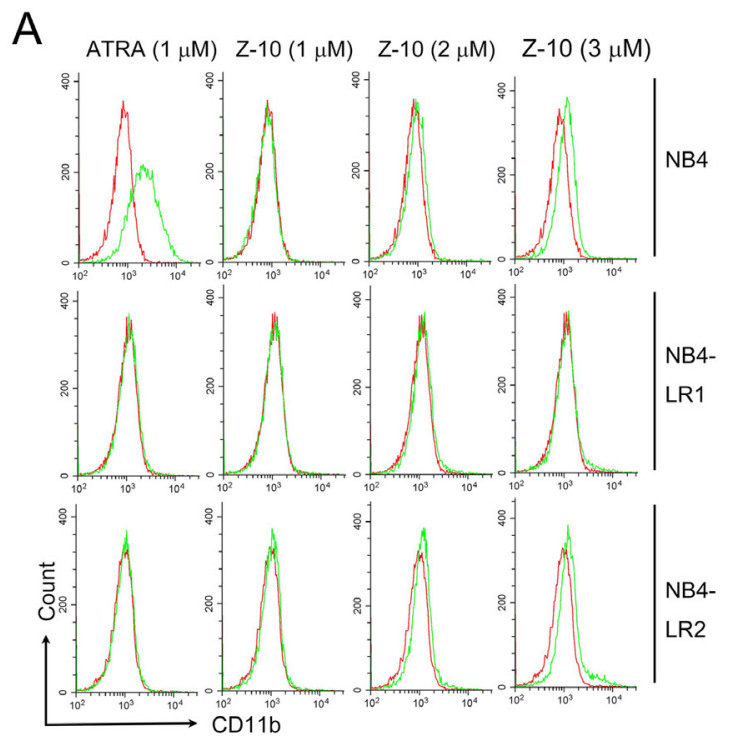

drug lead in a distinct class of RXR $\alpha$ ligands for APL treatment.

$\mathrm{RXR} \alpha$ forms strong heterotetramers with PML$\operatorname{RAR} \alpha$, and disruption of their interaction inhibits APL initiation and development $[24,25]$. $\operatorname{RXR} \alpha$ has been shown to be required for PML-RAR $\alpha$ sumoylation and efficiently binding to DNA, both of which are essential
$\mathrm{D}$

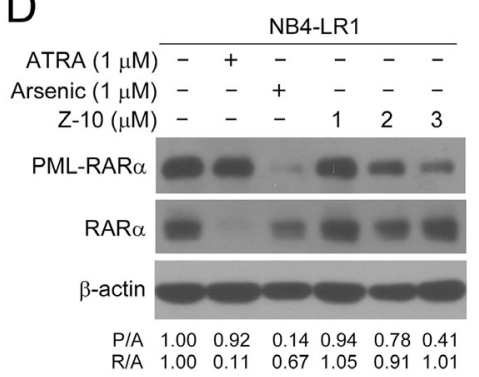

E

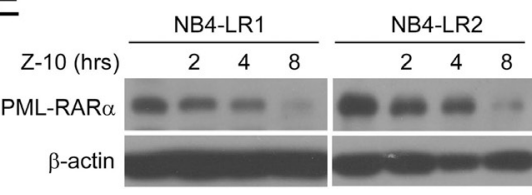

B
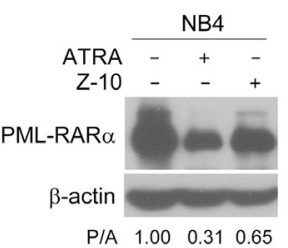

C

$$
\mathrm{Z}-10(\mu \mathrm{M})
$$

NB4-LR1

PML-RAR $\alpha$
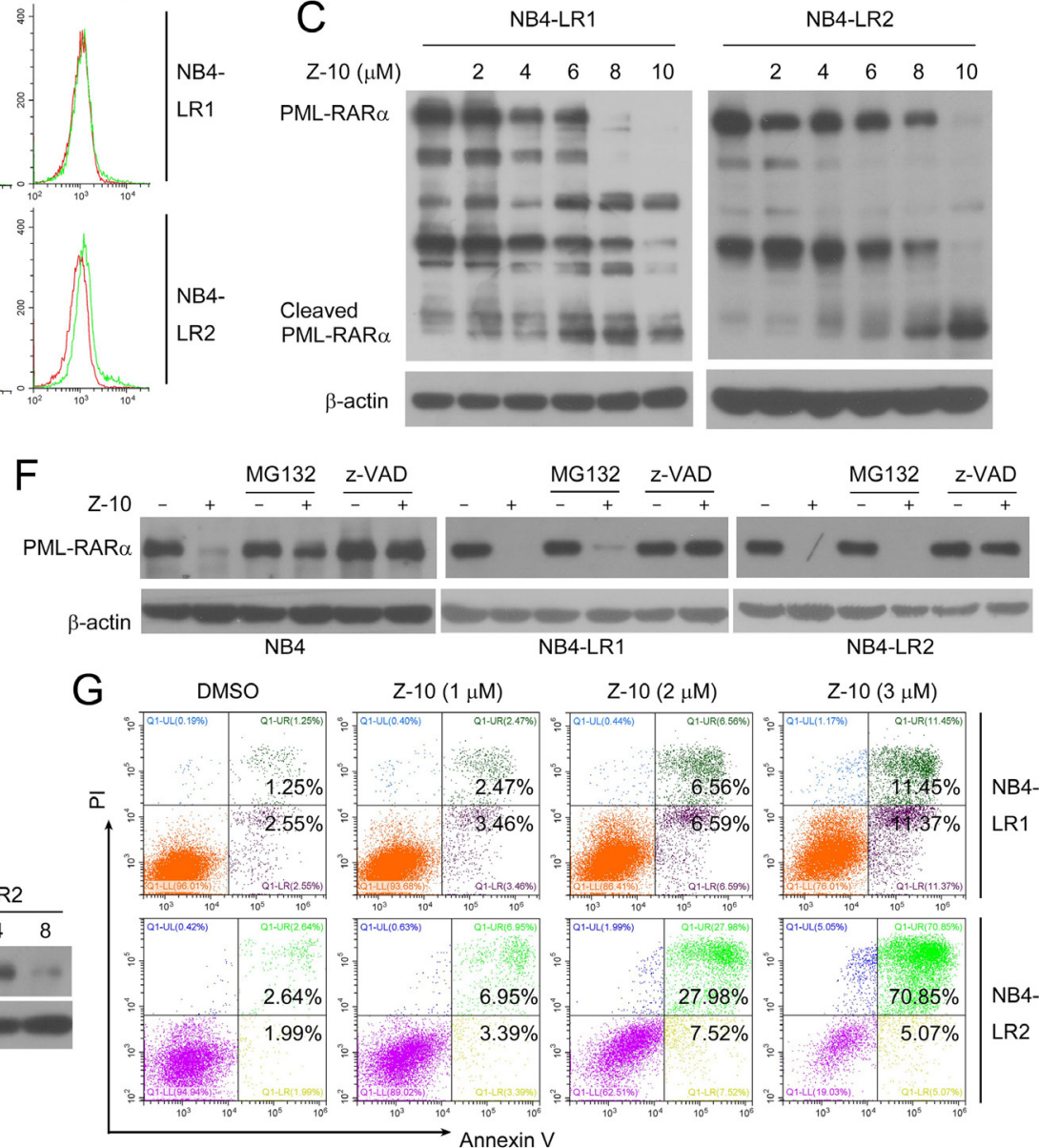

Figure 5: The induction of PML-RAR $\alpha$ degradation and apoptosis by Z-10 in ATRA-resistant NB4 cells. A. NB4, NB4LR1 or NB4-LR2 cells were incubated with Z-10 or ATRA for two days and CD11b-positive cells were counted by flow cytometry. Cells treated with DMSO were plotted in red, and cells treated with compounds were plotted in green. B. NB4 and NB4-LR2 cells were incubated with $1 \mu \mathrm{M}$ of Z-10 or ATRA for 48 hours. The PML-RAR $\alpha$ protein was detected by anti-RAR $\alpha$ antibody with $\beta$-actin as loading control. C. NB4-LR1 and NB4-LR2 cells were treated with Z-10 at the indicated concentration for 4 hours followed by western blot to examine protein expression. D. NB4-LR1 cells were incubated with Z-10, ATRA or arsenic at the indicated concentration for 48 hours. The PML RAR $\alpha$ and RAR $\alpha$ protein was detected by western blot using anti-RAR $\alpha$ antibody. Relative protein band densities after normalization to $\beta$-actin signal were shown at the bottom of the figure (P/A represents PML-RAR $\alpha / \beta$-actin, and R/A represents RAR $\alpha / \beta$-actin). E. Western blot analysis of PML-RAR $\alpha$ expression in NB4-LR1 and NB4-LR2 cells treated with $5 \mu \mathrm{M}$ of Z-10 for the indicated hours. F. NB4, NB4-LR1 and NB4LR2 cells were treated with $5 \mu \mathrm{M} \mathrm{Z-10} \mathrm{together} \mathrm{with} 20 \mu \mathrm{M}$ MG132 or $20 \mu \mathrm{M}$ z-VAD-FMK (z-VAD) for 4 hours, and protein expression was examined by western blot. G. NB4-LR1 and NB4-LR2 cells were incubated with Z-10 at the indicated concentrations for 36 hours, and the detection of apoptotic cells was carried out by Annexin V-FITC/PI double staining. 
events for APL transformation $[22,23]$. In our research, we unraveled that $\mathrm{RXR} \alpha$ was also vital for the stability of PML-RAR $\alpha$ (Figure 3), which provided a new mechanism underlying $\mathrm{RXR} \alpha$ actions in APL. It is conceivable that this contribution of $\operatorname{RXR} \alpha$ also originates from its interaction with PML-RAR $\alpha$. Therefore, a feasible approach to eliminate PML-RAR $\alpha$ is to abrogate its interaction with $\mathrm{RXR} \alpha$. Indeed, Z-10 could potently inhibit the interaction of PML-RAR $\alpha$ and RXR $\alpha$ (Figure
3C-3D and Figure 4C), leading to the caspase-mediated cleavage of PML-RAR $\alpha$ (Figure 2D). We hypothesized that the binding of $\mathrm{RXR} \alpha$ may preclude the cleavage of PML-RAR $\alpha$ through masking the cleavage sites or inhibiting the access of caspases. Figure $3 \mathrm{~A}$ indicated that PML-RAR $\alpha$ reduction induced by Z-10 preceded caspase activation, implying that basal activity of caspases was enough for catalyzing PML-RAR $\alpha$ cleavage once the PML-RAR $\alpha / \operatorname{RXR} \alpha$ complex was disrupted.

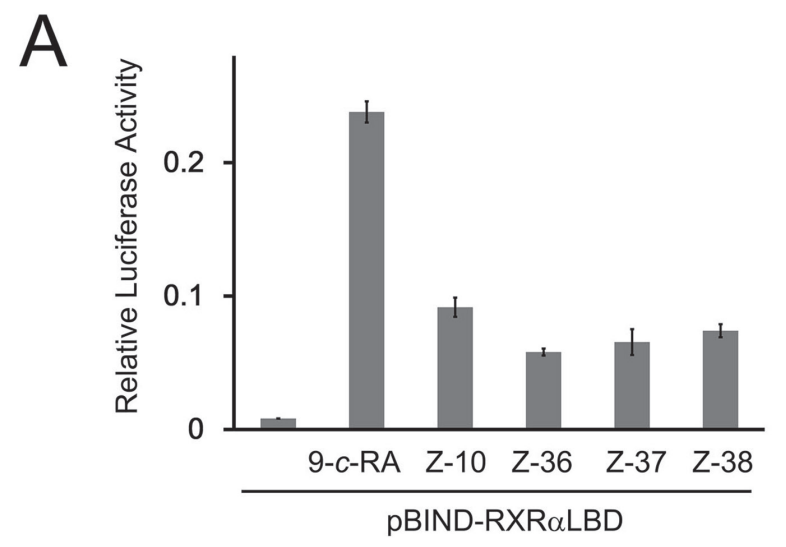

B

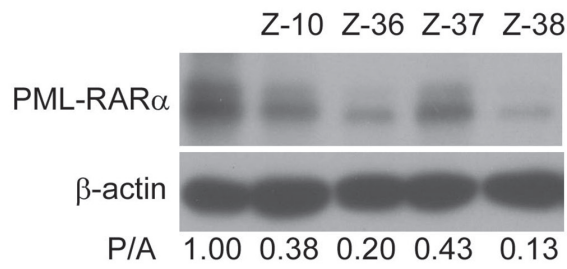

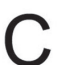

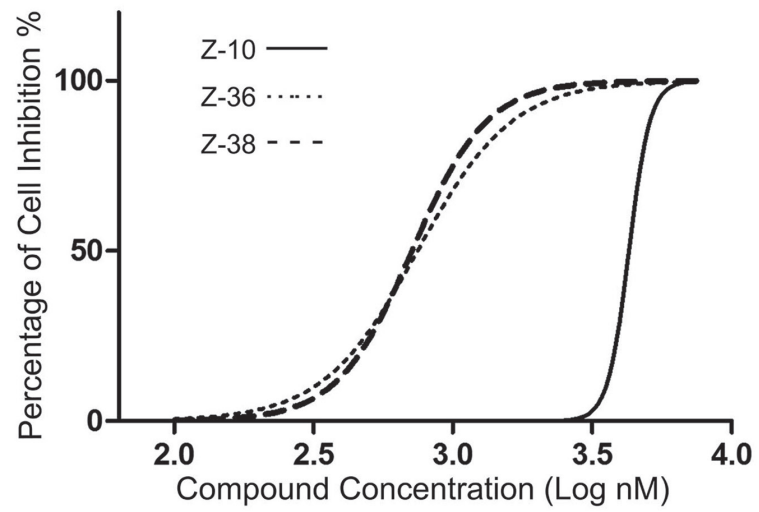

\begin{tabular}{|c|c|c|c|}
\hline Z compound & $I_{50}(\mathbf{n M})$ & $\mathbf{R}_{2}$ & $\begin{array}{c}\text { Number of points } \\
\text { Analyzed }\end{array}$ \\
\hline Z-10 & 4284 & 0.9462 & 9 \\
\hline Z-36 & 747.6 & 0.9366 & 9 \\
\hline Z-38 & 713 & 0.9652 & 9 \\
\hline
\end{tabular}

D
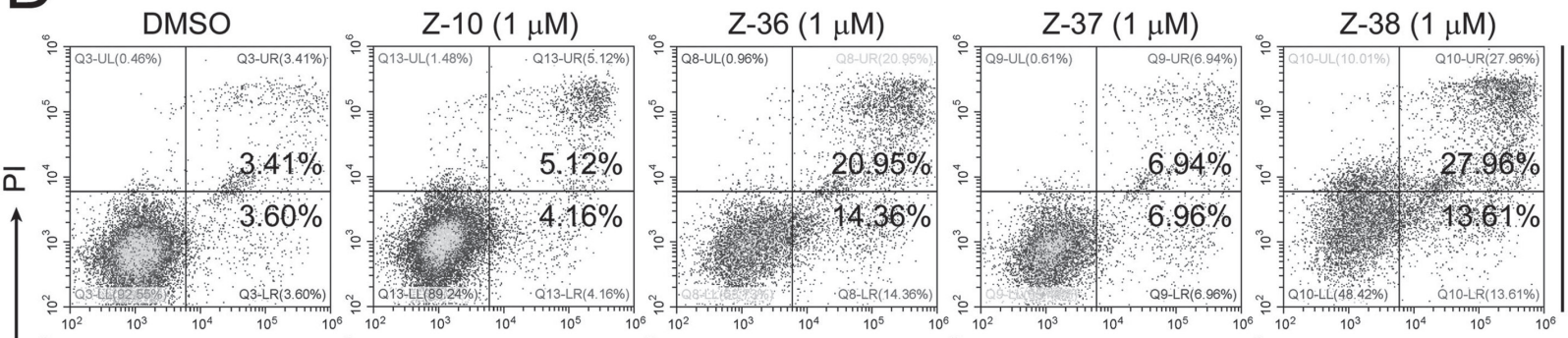

NB4
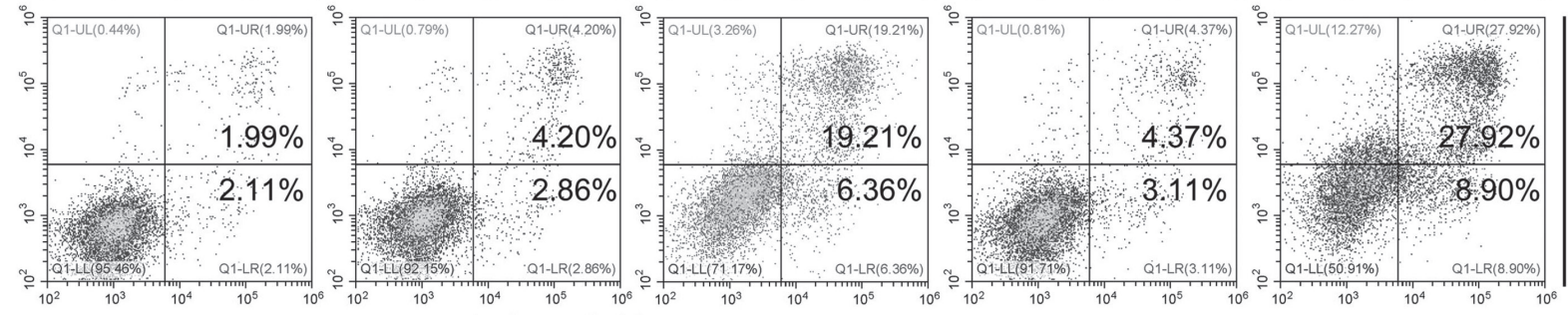

NB4-

Figure 6: Z-36 and Z-38 were optimized Z-10 derivatives. A. HEK293T cells were transfected with pBIND-RXR $\alpha$-LBD and pG5-luc for 24 hours, and treated with $0.1 \mu \mathrm{M} 9$-cis-RA $(9-c-\mathrm{RA})$ and the indicated compounds $(5 \mu \mathrm{M})$. Luciferase activities were measured 12 hours after treatment and relative luciferase activity was plotted. B. NB4 cells were treated with $5 \mu \mathrm{M}$ of the indicated compounds for 4 hours. The PML-RAR $\alpha$ protein was detected by anti-RAR $\alpha$ antibody with $\beta$-actin as loading control. C. NB4 cells were plated at a density of $1 \times 10^{5}$ cells $/ \mathrm{ml}$ in a 96-well plate. Cells were treated with Z-10 at increased concentrations $(0.1,0.5,1,2,3,4,5,6$, and $7.5 \mu \mathrm{M})$ for 36 hours, and cell proliferation was measured by MTS assay. Data were analyzed and plotted using GraphPad Prism software. D. NB4 and NB4-LR1 cells were incubated with $1 \mu \mathrm{M}$ of compounds as indicated for 36 hours, and the detection of apoptotic cells was carried out by Annexin V-FITC/PI double staining. 
Different from the heterodimer formed by RAR $\alpha$ and RXR $\alpha$, PML-RAR $\alpha$ and RXR $\alpha$ forms heterotetramer. In the heterotetramer, PML-RAR $\alpha$ not only interacts with RXR $\alpha$ through RAR $\alpha$ moiety, but also interacts with each other through PML moiety [23, 25]. These may underlie the different modes of RXR $\alpha$ interaction with PML-RAR $\alpha$ and RAR $\alpha$. It is conceivable that the conformational change induced by Z-10 may only affect RXR $\alpha$ interaction with PML-RAR $\alpha$ but not with $\operatorname{RAR} \alpha$, a possibility that was confirmed by our co immunoprecipitation assay (Figure 4C). Consistently, even though RXR $\alpha$ was vital for the stability of both PML-RAR $\alpha$ and RAR $\alpha, Z-10$ binding to $\mathrm{RXR} \alpha$ selectively reduced the stability of PMLRAR $\alpha$ (Figure 4A-4B and Figure 5D). This property might allow Z-10 to circumvent some of ATRA's side effects. RXR $\alpha$ could form heterodimers with many other nuclear receptors [40]. If $\mathrm{Z}-10$ did not affect $\mathrm{RXR} \alpha$ binding to $\mathrm{RAR} \alpha$, it likely has no or only minor effect on $\operatorname{RXR} \alpha$ heterodimerization with other nuclear receptors.

One limitation in APL treatment is ATRA resistance $[14,41]$. Due to the mutations of the RAR $\alpha$ moiety that directly affect the binding of ATRA, it should be difficult to solve this issue through modifying ATRA or using other RAR $\alpha$ ligands. Since Z-10 inhibited PML RAR $\alpha$ through binding to $\mathrm{RXR} \alpha$, it may overcome this problem. Indeed, our results showed that Z-10 induced PML-RAR $\alpha$ degradation and apoptosis in ATRA-resistant NB4 cells (Figure 5). This implied that $\operatorname{RXR} \alpha$ was also important to maintain the stability of the mutated PML RAR $\alpha$, and Z-10 was able to inhibit the interactions of $\mathrm{RXR} \alpha$ with the mutated PML-RAR $\alpha$. It remains to be investigated whether Z-10 could also overcome the arsenic-resistance.

Z-36 and Z-38 are two derivatives of Z-10 only after simple modifications (Figure 1A). However, these two derivatives had substantially improved potency (Figure 6B$6 \mathrm{D})$, which suggested that Z-10 can be further optimized in term of APL treatment. Animal studies of Z-10 and its derivatives will be needed to confirm their efficacy and study their potential side effects. It will also be interesting to study the synergistic effect of Z-10 and ATRA in animal experiments.

\section{MATERIALS AND METHODS}

\section{Reagents and antibodies}

Antibodies for RAR $\alpha$ (sc-551), RXR $\alpha$ (sc-553), PARP-1/2 (sc-7150), c-Myc (sc-40) were purchased from Santa Cruz Biotechnology; Antibody for $\beta$-actin (A2228), ATRA (R2625), SR11237 (S8951), LG 100754 (SML0771), Danthron (D108103), Arsenic, and 9-cis-RA (R4643) were purchased from Sigma-Aldrich; Antibody for human FITC-CD11b was from eBioscience; Antibody for Cleaved caspase-3 (\#9661) was from Cell Signaling Technology; PAC-1(Procaspase-activating compound-1) was from MedChem Express; UVI3003 (3303) was from
Tocris Bioscience; K-8003 and Z compounds were stored in our laboratory.

\section{Compound synthesis}

General procedure for the synthesis of Nitroolefins (Z-10, Z-11, Z-36, Z-37 and Z-38) was via the Henry reaction as previously described [28].

\section{Cell culture}

APL cell lines NB4 and NB4-derived ATRAresistant NB4-LR1 and NB4-LR2 were cultured in RPMI 1640 medium (Thermo Fisher Scientific). African green monkey kidney fibroblast-like cell COS-7 and human embryonic kidney cell 293T were cultured in DMEM medium (Thermo Fisher Scientific). The mediums were supplemented with $10 \%$ fetal bovine serum (FBS, Gibco), penicillin $(100 \mathrm{IU} / \mathrm{mL})$, and streptomycin $(100 \mu \mathrm{g} / \mathrm{mL})$, and the cells were maintained at a humidified incubator at $37{ }^{\circ} \mathrm{C}$ and $5 \% \mathrm{CO}_{2}$. For experiments, cells were incubated with compounds with $0.01-0.1 \%$ DMSO treatment as control.

\section{Plasmids and transfection}

PSG5-PML-RAR $\alpha$ plasmid was a gift from Dr. Jun Zhu (Shanghai Jiao-Tong University School of Medicine). Myc-RXR $\alpha / \mathrm{C} 432 \mathrm{~S}$ was constructed with standard methods. HA-RXR $\alpha$, Myc-RAR $\alpha$, Myc$\mathrm{RXR} \alpha, \mathrm{pBind}-\mathrm{RXR} \alpha-\mathrm{LBD}$, pGL6-TA-RXRE, pG5 were preserved in our laboratory. COS-7 cell transfections were carried out by using TurboFect Transfection Reagent (R0531, Fermentas) according to the instructions of the manufacturer. NB4 cell transfections were carried out by using retrovirus infection, and $\mathrm{RXR} \alpha$ shRNA sequence is CAAGGACTGCCTGATTGAC.

\section{Western blot}

Cells were lysed, and equal amounts of the lysates were loaded onto $8 \%$ sodium dodecylsulfatepolyacrylamide gel, electrophoresed, and transferred to polyvinylidene difluoride membranes (Millipore). The membranes were blocked with 5\% skimmed milk in TBST (50 mM Tris- $\mathrm{HCl}$ [pH 7.4], $150 \mathrm{mM} \mathrm{NaCl}$, and $0.1 \%$ Tween 20) for 1 hour and then incubated with primary antibodies overnight at $4^{\circ} \mathrm{C}$, followed by secondary antibodies for 2 hours at room temperature. The detection was performed by the ECL system (Thermo). $\beta$-actin was used as an internal control. Protein band density was quantified using software Quantity One-4.6.2.

\section{Co-immunoprecipitation assay}

Cells were harvested and lysed in buffer containing $20 \mathrm{mM}$ Tris- $\mathrm{HCl}(\mathrm{pH} 7.5), 150 \mathrm{mM} \mathrm{NaCl}$, 
$1 \mathrm{mM}$ EDTA, $1 \mathrm{mM}$ EGTA, 1\% Triton X-100, 2.5 $\mathrm{mM}$ sodium pyrophosplate, $1 \mathrm{mM} \beta$-glycerophosplate and $1 \mathrm{mM} \mathrm{Na}_{3} \mathrm{VO}_{4}$, with proteinase inhibitor cocktail. Immunoprecipitation was performed as previously described $[28,42,43]$.

\section{Apoptosis and differentiation assay}

Three-milliliter cultures of NB4, NB4-LR1 and NB4-LR2 cells at a density of $3 \times 10^{5}$ cells $/ \mathrm{mL}$ were incubated with compounds and equal amount of DMSO for 36 hours. The apoptosis of the cells was detected using FITC Annexin V Apoptosis Detection Kit I (556547, $\mathrm{BD}$ Biosciences) according to the instructions of the manufacturer. Cell surface differentiation antigen CD11b was measured using fluorescein isothiocyanate-labeled antibodies with isotype controls via flow cytometry.

\section{MTS assay}

NB4 cells were seeded in 96-well culture plate at a cell density of $1 \times 10^{5}$ cells $/ \mathrm{mL}$ and treated with compounds for 36 hours. The cell viability was evaluated using an MTS assay kit (Promega, G3580). Briefly, MTS (10 mg/ml, 3-(4,5 dimethylthiazol-2yl)-5-(3-carboxymethoxyphenyl)-2 (4-sulfophenyl)$2 \mathrm{H}$-tetrazolium) was added to each well followed by incubation for 2 hours at $37{ }^{\circ} \mathrm{C}$. The absorbance was measured at a wavelength of $490 \mathrm{~nm}$ using an ElisaReader.

\section{Mammalian one-hybrid assay}

293T cells were cotransfected with pG5-luc reporter (Promega) together with the RXR $\alpha$-LBD fused with the DNA-binding domain of Gal4. After 24 hours, cells were treated with DMSO, Z compounds, or 9-cis- RA. After 12 hours, cells were lysed by passive lysis buffer. Firefly and Renilla luciferase activities were quantitated using the Dual-Luciferase Reporter Assay System (Promega, E1960). Transfection and expression efficiency was normalized to Renilla luciferase activity.

\section{Statistical analysis}

Results were derived at least three independent experiments and shown as the mean \pm standard deviation. The student's $t$-test was applied for the statistic analysis, and $p<0.05$ was considered significant.

\section{ACKNOWLEDGMENTS AND FUNDING}

We thank Dr. Guo-qiang Chen, Dr. Ying-li Wu and Dr. Jun Zhu from Shanghai Jiao-Tong University School of Medicine for kindly providing NB4, NB4-LR1 and NB4-LR2 cells, and PSG5-PML-RAR $\alpha$ expression plasmid. This work was supported by the grants from the
National Nature Science Fund of China (NSFC-31471318, NSFC-31271453, NSFC-91129302 and NSFC-81301888), the National Institutes of Health (CA140980, GM089927).

\section{CONFLICTS OF INTEREST}

The authors declare no competing financial interests.

\section{REFERENCES}

1. Coombs CC, DeAngelis LM, Feusner JH, Rowe JM, Tallman MS. Pseudotumor Cerebri in Acute Promyelocytic Leukemia Patients on Intergroup Protocol 0129: Clinical Description and Recommendations for New Diagnostic Criteria. Clin Lymphoma Myeloma Leuk. 2016; 16:146-151.

2. Wang ZY, Chen Z. Acute promyelocytic leukemia: from highly fatal to highly curable. Blood. 2008; 111:2505-2515.

3. Tussie-Luna MI, Rozo L, Roy AL. Pro-proliferative function of the long isoform of PML-RARalpha involved in acute promyelocytic leukemia. Oncogene. 2006; 25:3375-3386.

4. Ablain J, de The H. Retinoic acid signaling in cancer: The parable of acute promyelocytic leukemia. Int J Cancer. 2014; 135:2262-2272.

5. Bernardi R, Pandolfi PP. Role of PML and the PML-nuclear body in the control of programmed cell death. Oncogene. 2003; 22:9048-9057.

6. Bernardi R, Pandolfi PP. Structure, dynamics and functions of promyelocytic leukaemia nuclear bodies. Nat Rev Mol Cell Biol. 2007; 8:1006-1016.

7. de The H, Chen Z. Acute promyelocytic leukaemia: novel insights into the mechanisms of cure. Nat Rev Cancer. 2010; 10:775-783.

8. Nasr R, Lallemand-Breitenbach V, Zhu J, Guillemin MC, de The H. Therapy-induced PML/RARA proteolysis and acute promyelocytic leukemia cure. Clin Cancer Res. 2009; 15:6321-6326.

9. Nervi C, Ferrara FF, Fanelli M, Rippo MR, Tomassini B, Ferrucci PF, Ruthardt M, Gelmetti V, Gambacorti-Passerini C, Diverio D, Grignani F, Pelicci PG, Testi R. Caspases mediate retinoic acid-induced degradation of the acute promyelocytic leukemia PML/RARalpha fusion protein. Blood. 1998; 92:2244-2251.

10. Zhu J, Gianni M, Kopf E, Honore N, Chelbi-Alix M, Koken M, Quignon F, Rochette-Egly C, de The H. Retinoic acid induces proteasome-dependent degradation of retinoic acid receptor alpha (RARalpha) and oncogenic RARalpha fusion proteins. Proc Natl Acad Sci U S A. 1999; 96:14807-14812.

11. Hatake K, Uwai M, Ohtsuki T, Tomizuka H, Izumi T, Yoshida M, Miura Y. Rare but important adverse effects of all-trans retinoic acid in acute promyelocytic leukemia and their management. Int J Hematol. 1997; 66:13-19. 
12. Su YC, Dunn P, Shih LY, Kuo MC, Chang H, Wu JH, Lin TL, Wang PN, Tang TC, Hung YS. Retinoic acid syndrome in patients following the treatment of acute promyelocytic leukemia with all-trans retinoic acid. Chang Gung medical journal. 2009; 32:535-542.

13. Tomita A, Kiyoi H, Naoe T. Mechanisms of action and resistance to all-trans retinoic acid (ATRA) and arsenic trioxide (As2O 3) in acute promyelocytic leukemia. Int J Hematol. 2013; 97:717-725.

14. Gallagher RE. Retinoic acid resistance in acute promyelocytic leukemia. Leukemia. 2002; 16:1940-1958.

15. Zhang XW, Yan XJ, Zhou ZR, Yang FF, Wu ZY, Sun HB, Liang WX, Song AX, Lallemand-Breitenbach V, Jeanne M, Zhang QY, Yang HY, Huang QH, Zhou GB, Tong JH, Zhang Y, et al. Arsenic trioxide controls the fate of the PML-RARalpha oncoprotein by directly binding PML. Science. 2010; 328:240-243.

16. Lallemand-Breitenbach V, Jeanne M, Benhenda S, Nasr R, Lei M, Peres L, Zhou J, Zhu J, Raught B, de The H. Arsenic degrades PML or PML-RARalpha through a SUMOtriggered RNF4/ubiquitin-mediated pathway. Nat Cell Biol. 2008; 10:547-555.

17. Lallemand-Breitenbach V, Zhu J, Chen Z, de The H. Curing APL through PML/RARA degradation by As2O3. Trends Mol Med. 2012; 18:36-42.

18. Lou Y, Ma Y, Sun J, Ye X, Pan H, Wang Y, Qian W, Meng H, Mai W, He J, Tong H, Jin J. Evaluating frequency of PML-RARA mutations and conferring resistance to arsenic trioxide-based therapy in relapsed acute promyelocytic leukemia patients. Ann Hematol. 2015; 94:1829-1837.

19. Zhu HH, Qin YZ, Huang XJ. Resistance to arsenic therapy in acute promyelocytic leukemia. N Engl J Med. 2014; 370:1864-1866.

20. Evans RM, Mangelsdorf DJ. Nuclear Receptors, RXR, and the Big Bang. Cell. 2014; 157:255-266.

21. Ablain J, de The H. Revisiting the differentiation paradigm in acute promyelocytic leukemia. Blood. 2011; 117:5795-5802.

22. Zhu J, Zhou J, Peres L, Riaucoux F, Honore N, Kogan S, de The H. A sumoylation site in PML/RARA is essential for leukemic transformation. Cancer Cell. 2005; 7:143-153.

23. Vitaliano-Prunier A, Halftermeyer J, Ablain J, de Reynies A, Peres L, Le Bras M, Metzger D, de The H. Clearance of PML/RARA-bound promoters suffice to initiate APL differentiation. Blood. 2014; 124:3772-3780.

24. Zeisig BB, Kwok C, Zelent A, Shankaranarayanan P, Gronemeyer H, Dong S, So CW. Recruitment of RXR by homotetrameric RARalpha fusion proteins is essential for transformation. Cancer Cell. 2007; 12:36-51.

25. Zhu J, Nasr R, Peres L, Riaucoux-Lormiere F, Honore N, Berthier C, Kamashev D, Zhou J, Vitoux D, Lavau C, de The H. RXR is an essential component of the oncogenic PML/RARA complex in vivo. Cancer Cell. 2007; 12:23-35.
26. Benoit G, Altucci L, Flexor M, Ruchaud S, Lillehaug J, Raffelsberger W, Gronemeyer H, Lanotte M. RARindependent RXR signaling induces $\mathrm{t}(15 ; 17)$ leukemia cell maturation. EMBO J. 1999; 18:7011-7018.

27. Altucci L, Rossin A, Hirsch O, Nebbioso A, Vitoux D, Wilhelm E, Guidez F, De Simone M, Schiavone EM, Grimwade D, Zelent A, de The H, Gronemeyer H. Rexinoid-triggered differentiation and tumor-selective apoptosis of acute myeloid leukemia by protein kinase A-mediated desubordination of retinoid $\mathrm{X}$ receptor. Cancer Res. 2005; 65:8754-8765.

28. Zeng Z, Sun Z, Huang M, Zhang W, Liu J, Chen L, Chen F, Zhou Y, Lin J, Huang F, Xu L, Zhuang Z, Guo S, Alitongbieke G, Xie G, Xu Y, et al. Nitrostyrene Derivatives Act as RXRalpha Ligands to Inhibit TNFalpha Activation of NF-kappaB. Cancer Res. 2015; 75:2049-2060.

29. Lanotte M, Martin-Thouvenin V, Najman S, Balerini P, Valensi F, Berger R. NB4, a maturation inducible cell line with $\mathrm{t}(15 ; 17)$ marker isolated from a human acute promyelocytic leukemia (M3). Blood. 1991; 77:1080-1086.

30. Gu ZM, Wu YL, Zhou MY, Liu CX, Xu HZ, Yan H, Zhao Y, Huang Y, Sun HD, Chen GQ. Pharicin B stabilizes retinoic acid receptor-alpha and presents synergistic differentiation induction with ATRA in myeloid leukemic cells. Blood. 2010; 116:5289-5297.

31. Cao Y, Wei W, Zhang N, Yu Q, Xu WB, Yu WJ, Chen GQ, $\mathrm{Wu}$ YL, Yan H. Oridonin stabilizes retinoic acid receptor alpha through ROS-activated NF-kappaB signaling. BMC Cancer. 2015; 15:248.

32. Lallemand-Breitenbach V, de The H. Retinoic acid plus arsenic trioxide, the ultimate panacea for acute promyelocytic leukemia? Blood. 2013; 122:2008-2010.

33. Lo-Coco F, Avvisati G, Vignetti M, Thiede C, Orlando SM, Iacobelli S, Ferrara F, Fazi P, Cicconi L, Di Bona E, Specchia G, Sica S, Divona M, Levis A, Fiedler W, Cerqui E, et al. Retinoic acid and arsenic trioxide for acute promyelocytic leukemia. N Engl J Med. 2013; 369:111-121.

34. Roussel MJ, Lanotte M. Maturation sensitive and resistant $\mathrm{t}(15 ; 17)$ NB4 cell lines as tools for APL physiopathology: nomenclature of cells and repertory of their known genetic alterations and phenotypes. Oncogene. 2001; 20:7287-7291.

35. Zhang TD, Chen GQ, Wang ZG, Wang ZY, Chen SJ, Chen $Z$. Arsenic trioxide, a therapeutic agent for APL. Oncogene. 2001; 20:7146-7153.

36. Degos L, Wang ZY. All trans retinoic acid in acute promyelocytic leukemia. Oncogene. 2001; 20:7140-7145.

37. Lehmann-Che J, Bally C, de The H. Resistance to therapy in acute promyelocytic leukemia. N Engl J Med. 2014; 371:1170-1172.

38. Nasr R, Guillemin MC, Ferhi O, Soilihi H, Peres L, Berthier C, Rousselot P, Robledo-Sarmiento M, LallemandBreitenbach V, Gourmel B, Vitoux D, Pandolfi PP, Rochette-Egly C, Zhu J, de The H. Eradication of acute 
promyelocytic leukemia-initiating cells through PMLRARA degradation. Nat Med. 2008; 14:1333-1342.

39. Kamashev D, Vitoux D, De The H. PML-RARA-RXR oligomers mediate retinoid and rexinoid/cAMP cross-talk in acute promyelocytic leukemia cell differentiation. J Exp Med. 2004; 199:1163-1174.

40. Szanto A, Narkar V, Shen Q, Uray IP, Davies PJ, Nagy L. Retinoid X receptors: X-ploring their (patho) physiological functions. Cell Death Differ. 2004; 11:S126-143.

41. Freemantle SJ, Spinella MJ, Dmitrovsky E. Retinoids in cancer therapy and chemoprevention: promise meets resistance. Oncogene. 2003; 22:7305-7315.
42. Zhang L, Zhou H, Su Y, Sun Z, Zhang H, Zhang L, Zhang Y, Ning Y, Chen YG, Meng A. Zebrafish Dpr2 inhibits mesoderm induction by promoting degradation of nodal receptors. Science. 2004; 306:114-117.

43. Zhou H, Liu W, Su Y, Wei Z, Liu J, Kolluri SK, Wu H, Cao Y, Chen J, Wu Y, Yan T, Cao X, Gao W, Molotkov A, Jiang F, Li WG, et al. NSAID sulindac and its analog bind RXRalpha and inhibit RXRalpha-dependent AKT signaling. Cancer Cell. 2010; 17:560-573. 